\title{
Pembinaan Dan Sosialisasi Bahaya Narkoba Kepada Masyarakat Berdasarkan Undang-Undang Nomor 35 Tahun 2009 tentang Narkotika Demi Tercapainya Tujuan Berbangsa Dan Bernegara
}

\author{
Zainuri, Dian Novita \\ Universitas Wiraraja \\ Email : zainuri@wiraraja.ac.id \\ Email: dian.fh@wiraraja.ac.id \\ Abstrak
}

Narkotika adalah zat atau obat yang berasal dari tanaman atau bukan tanaman, baik sintetis maupun semisintetis,yang dapat menyebabkan penurunan atau perubahan kesadaran, hilangnya rasa, mengurangi sampai menghilangkan rasa nyeri, dan dapat menimbulkan ketergantungan, yang dibedakan ke dalam golongan-golongan sebagaimana terlampir dalam Undang-Undang. Maraknya pengidaran dan penyalahgunaan norkotika di masyarakat setiap tahun selalu bertambah tidak terkecuali masyarakat yang ada di desa matanir kecamatan rubaru kabupaten sumenep. Dalam pelaksanaan pengabdian ini kami menggunakan pendekantan Undang-undang yakni Undang-Undang Nomor 35 Tahun 2009 tentang Narkotika melalui pendekatan seperti ini masyarakat akan memahami terhadap dampak dari narkotika termasuk proses jika terjadi kasus di masyarakat.

Key Word: Narkotika dan Masyarakat

\section{A. Pendahuluan}

Penyalah gunaan narkoba di masyarakat indonesia semakin marak setiap tahunnya ,sehingga hal tersebut dijadikan masalah nasional. Penyalahgunaan narkotika tidak saja merambah di wilayah perkotaan, tetapi mulai merambah ke wilayah pedesaan. Pengidar dan pengguna narkotika tanpa melihat faktor usia, strata sosial bahkan jenis kelamin semua menjadi incaran dari penyalahgunaan narkotika.

Sasaran utama pengidar dan pengguna narkotika adalah para generasi muda, hal tersebut menjadi tugas dari semua elemen yang ada di negara Indonesia, sedangkan generasi muda adalah tonggak harapan suatu negara untuk mencapai cita-cita negara

Pengidaran dan penggunaan narkoba bukan saja merupakan masalah yang perlu mendapat perhatian bagi lembaga negara Indonesia, melainkan juga bagi lembaga pendidikanI, karena lembaga pendidikan dituntut untuk ikut serta dalam mencerdaskan kehidupan bangsa, yang di dalamnya adalah memerangi peredaran dan penyalahgunaan narkoba di masyarakat dn menjelaskan dampak dari narkoba dan ancaman sanksinya.

Indonesia melaluai lembaga parlemen telah membentuk UndangUndang Nomor 35 Tahun 2009 Tentang Narkotika. Dalam undang-undang tersebut menyatakan bahwa Narkotika adalah zat atau obat yang berasal dari tanaman atau bukan tanaman, baik sintetis maupun semisintetis,yang dapat menyebabkan penurunan atau perubahan kesadaran, hilangnya rasa, mengurangi sampai menghilangkan rasa nyeri, dan dapat menimbulkan ketergantungan, yang dibedakan ke dalam golongangolongan sebagaimana terlampir dalam Undang-Undang. 


\section{B. Metode}

Pengabdian Masyarakat ini menggunakan Metode pendekatan persuasive terlebih dahulu kepada masyarakat setelah itu baru kemudian tim menhubungi kepala desa dan mendekati tokoh masyarakat serta beberapa stake holder untuk dapatnya membantu terlaksananya pengabdian kepada masyarakat oleh tim. Kerjasama yang dilakukan bertujuan agar nantinya stakeholder dapat memberikan informasi kepada masyarakat yang lain bahwa akan diadakan sosialisasi dan pendampingan hukum mengenai UU Narkotika dan dampaknya.

Berbagai permasalahan yang dihadapi oleh masyarakat Desa Matanair kecamatan rubaru dapat di tanggulangi dengan melihat potensi dari Sumber Daya Manusia. Hal ini dikarenakan masyarakat dari desa tersebut mayoritas berpendidikan SMA, hanya saja ketidak tauan dan kurangnya pemahaman masyarakat dan kurangnya rasa kesadaran dari masyarakat terhadap bahaya narkoba serta sanksi-sanksi yang diancamkan terhadap pelaku narkoba dan lain sebagainya.

Untuk membangun desa yang bebas dari narkoba dan yang taat aturan selain harus dimulai dari diri sendiri, desa mempunyai peranan penting dalam pembangunan desa yang bebas dari narkobak. Perlu dipahami bersama bahwa untuk membangun desa yang baik dan taat akan hukum di butuhkan tiga (3) Komponen dasar : yang pertama Aturan yang baik, yang kedua masyarakat yang taat hukum kemudian yang ketiga adalah pemerintahan desa yang responsif terhadap kejala-gejala yang ada dimsyarakatnya.

Adapun tahapan-tahapan dalam kegiatan pengabdian kepada masyarakat yang dilakuakan oleh tim adalah sebagai berikut:

1. Sosialisasi
Sosialisasi dilakukan setelah adanya kepastian dari LPPM UNIJA tentang kegiatan ini dan dimaksudkan untuk melihat kesiapan lokasi dan sasaran atau mitra sebagai potret awal desa yang dijadikan mira dalam kegiatan.

2. Penyusunan materi kegiatan

Penyusunan materi kegiatan / penyuluhan dilakukan dengan bekerja sama dengan berbagaipihak agar nantinya mendapatkan kesepakan untuk dilaksanakannya kegiatan dengan menampilkan demonstrasi beberapa kasus tentang narkotika.

3. Penyiapan sarana dan prasarana

Sarana dan prasarana yang pelu dipersiapkan pada kegiatan ini meliputi; (1) Alat dan bahan pendampingan dan sosialisasi seperti Hand out, Infocus, daftar hadir peserta dan lain sebagainya.

4. Pelaksanaan pendampinga dan sosialisasi

Tim melakukan sosialisasi dan pendampingan dengan memberikan pemahaman tentang Bagaimana pengaturan mengenai narkoba,serta Bagaimana pendapingan terhadap pelaku maupun korban narkotika menurut UU tentang Narkotika. Pada saat sosialisasi dan pendampingan tim memberi kesempatan untuk mengajukan pertanyaan bagi peserta yang belum memahami secara maksud dan tujuan ( Diskusi ).

\begin{tabular}{|c|c|l|}
\hline No. & Tanggal & \multicolumn{2}{|c|}{ Kegiatan } \\
\hline & & $\begin{array}{l}\text { Tim pengabdian kepada } \\
\text { masyarakat melakukan } \\
\text { pertemuan dengan kepala } \\
\text { desa Matanair terkait } \\
\text { dengan akan } \\
\text { dilaksanakannya kegiatan } \\
\text { pendampingan hukum } \\
\text { tentang pendampingan } \\
\text { dan sosialisasi tentang } \\
\text { narkotika }\end{array}$ \\
\hline
\end{tabular}




\begin{tabular}{|c|c|c|}
\hline 2. & 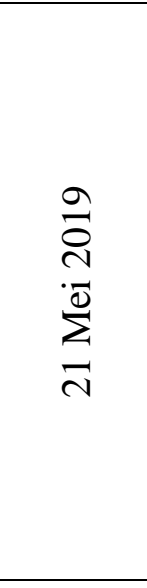 & $\begin{array}{l}\text { Setelah melakukan } \\
\text { pertemuan dengan kepala } \\
\text { desa Matanair, tim juga } \\
\text { mengadakan pendekatan } \\
\text { pada tokoh masyarakat } \\
\text { desa Matanair dengan } \\
\text { menyampaikan akan } \\
\text { mengadakan penyuluhan } \\
\text { hukum dengan maksud } \\
\text { ingin memberikan } \\
\text { pemahaman kepada } \\
\text { masyarakat sekitar }\end{array}$ \\
\hline 3. & 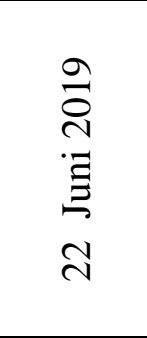 & $\begin{array}{l}\text { Tim juga melakukan } \\
\text { pendekatan dengan para } \\
\text { beberapa masyarakat } \\
\text { Desa Matanair dengan } \\
\text { menyampaikan niat akan } \\
\text { mengadakan penyuluhan } \\
\text { hukum tentang narkotika }\end{array}$ \\
\hline 4. & 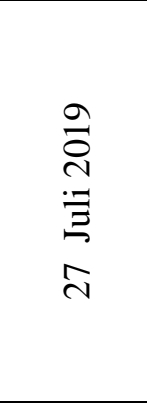 & $\begin{array}{l}\text { Tim Pengabdian Kepada } \\
\text { Masyarakat (PKM) kembali } \\
\text { mengadakan pertemuan } \\
\text { dengan perangkat desa dan } \\
\text { masyarakat terkait dengan } \\
\text { menentukan waktu dan } \\
\text { tempat kegiatan agar tidak } \\
\text { mengganggu aktivitas } \\
\text { masyarakat sehari-hari. }\end{array}$ \\
\hline 5. & 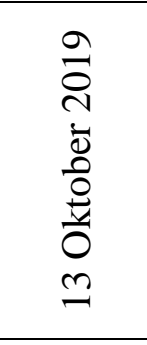 & $\begin{array}{lr}\text { Pelaksanaan } & \text { kegiatan } \\
\text { penyuluhan } & \text { hukum } \\
\text { dengan } & \text { memberikan } \\
\text { pemahaman } & \text { tentang } \\
\text { pendampingan } & \text { dan } \\
\text { sosialisasi } & \text { dampak } \\
\text { narkotika } & \\
\end{array}$ \\
\hline 6. & 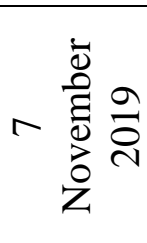 & $\begin{array}{l}\text { Evaluasi pelaksanaan } \\
\text { kegiatan penyuluhan } \\
\text { hukum dengan maksud } \\
\text { untuk mengetahui tingkat } \\
\text { pemahaman peserta. }\end{array}$ \\
\hline
\end{tabular}

5. Pemantauan dan refleksi

Pada saat kegiatan berlangsung, setiap tahapan proses akan dilakukan pemantauan dan dicermati/dikendalikan, sesuai dengan rencana dan tujuan yang telah ditetapkan. Bila terjadi suatu keadaan yang di luar perhitungan, maka akan segera dilakukan langkah penyesuaian dan tindakan perbaikan.

Setelah kegiatan dalam satu siklus/periode selesai, dilakukan refleksi untuk mengevaluasi apakah proses pada setiap tahapan kegiatan dan hasil telah sesuai dengan rencana. Kemudian tindak lanjut apa yang perlu dilakukan? Melalui refleksi/evaluasi ini, warga desa matanair dapat belajar banyak dari pengalaman maupu UU. Perbaikan-perbaikan yang dilakukan dari hasil refleksi/evaluasi kegiatan ini, akan menjamin terlaksananya program Sosialisasi dan pendampinganini secara berkesinambungan dan berkelanjutan, untuk membentuk masyarakat yang sadar akan hukum.

\section{Hasil dan pembahasan}

Pada pelaksanaan pengabdian kepada masyarakat yang dilakukan oleh Tim PKM dari Fakultas Hukum Universitas Wiraraja menjelaskan tentang bahaya narkotika, sanksi hukum, jenisjenis narkotika dan proses hukum bagi pihak-pihak yang meyalahgunakan narkotika.

Banyaknya masyarakat dan aparat desa yang ikut andil dalam pelaksanaan sosialisasi dan pendampingan UU Narkotika, serta banyaknya pertanyaan pertanyaan yang diajukan oleh masyarakat terkait dengan bahaya narkotika, sanksi hukum, jenis-jenis narkotika dan prosedur hukum ketika terjadi pelanggaran oleh masyarakat.

Harapan kami nantinya setelah selesainya pengabdian kepada masyarakat ini akan mendapatkan hasil yang maksimal yaitu dapat mewujudkan masyarakat bebas dari narkoba yang merupakan cikal bakal dalam membangaun bangsa dan negara, serta mengoptimalkan penegakan hukumnya.

$$
\text { Faktor Pendorong dan }
$$

Penghambat. Dari pembahasan tersebut kami mendapatkan beberapa masukan sehingg tim merangkumnya, seperti : 
a. Banyaknya masyarakat yang belum mengerti atau tidak mengetahui tentang narkotika, bahaya narkotika dan sanksi yang akan diberikan kepada pelanggar terhadap UU narkotika.

b. Banyaknya masyarakat yang belum mengetahui tentang adanya UU Narkotika.

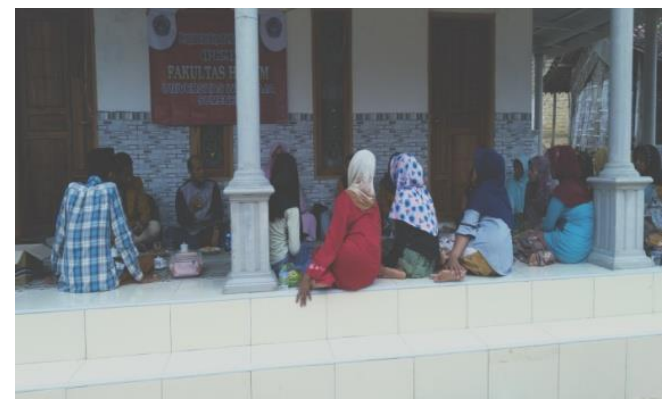

Dokumentasi saat pelaksanaan PKM

\section{Kesimpulan}

Berdasarkan hasil sosialisasi dan pendampingan terhadap masyarakat dari bahaya narkotika, masyarakat sangat sanagat responsip terhadap UU narkotika untuk bisa menjadi payung hukum ketika terjadi pelanggaran dan menyadarkan masyarakat akan bahaya dari narkotika. Selain itu masyarakat berharap adanya tindak lanjut dari UU Narkotika supaya bisa di implementasikan dengan baik dan menganding pemerintah-pemerintah yang ada di desa.

\section{E. DAFTAR BACAAN}

Aziz Syamsuddin, Tindak Pidana Khusus, Jakarta sinar Grafika, 2016

Adi, Kusno, Kebijakan Kriminal dalam Penanggulangan Tindak Pidana Narkotika Oleh Anak, UMM Press, Malang, 2009

Undang-Undang Nomor 35 Tahun 2009 Tentang Narkotika 